\title{
Teachers' Readiness in Promoting 21st Century Skills in Teaching Students at a Bilingual Primary School
}

\author{
Ni Nyoman Padmadewi*, Luh Putu Artini, I Nyoman Laba Jayanta \\ Universitas Pendidikan Ganesha \\ Bali, Indonesia \\ *nym.padmadewi@undiksha.ac.id, putu.artini@undiksha.ac.id, laba.jayanta@undiksha.ac.id
}

\begin{abstract}
Teachers' readiness is an important aspect to be considered in promoting 21st-century skills in teaching primary school students. Some studies have been conducted on teachers' readiness. However, the study on teachers' readiness to promote 21st-century skills in a bilingual context has never been conducted. This study aims to analyze the teachers' readiness to promote 21st-century teaching primary school students in a bilingual school. The readiness was analyzed from the teachers' perceived and observed readiness to implement 21st-century skills in teaching primary school students. The study was conducted using a mixed-method design, and the subjects involved 11 school teachers teaching at a bilingual primary school. The data were collected using questionnaires, observation, and interviews. Then, they were analyzed quantitatively and qualitatively. The study results show that the teachers perceived themselves as very ready to implement the 21 st-century skills, and the observations reconfirm it. The teachers implemented the 21st-century skills well across several programs conducted in classroom practices and at the school level. It is implied that the teachers have professional competencies in promoting 21stcentury skills in teaching their students.
\end{abstract}

\section{Keywords-teachers' readiness, twenty-first-century skills}

\section{INTRODUCTION}

The world nowadays recognizes increased globalization, which is characterized by 21 st-century education. 21 st-century education is the period that closes to globalization and internationalization [1]. To be ready to live in this globalization era, 21st-century skills are demanded by every individual. The 21st-century education framework involves various skills, namely life and carrier skills, learning and innovation skills, digital literacy skills, and supported with understanding interdisciplinary 21 st-century themes [2].

The 21st-century skills put students to thrive in a world that always increasingly involves cooperation, critical thinking, adaptability, grit, tenacity, and rely less on this education of facts and information. The how and why of teaching grows centered, and they are far more valuable than those what or who from the previous paradigm of teaching. Students must experience life-long education with a flexible attitude as they control 21st-century topics. They must take with and listen to the diversity point of view.

Education direction nowadays demands teachers to improve their skills, adapt, and prepare themselves to face the changes. They have to be ready. Readiness is defined as the individual's condition to respond to specific situations [3]. The globalization demands of having 21 st-century skills must be therefore responded to by teachers to prepare students to have life and career skills, build networking and make collaborations, be creative, promote innovation, develop the character of problem solver, and have critical thinking. All of these skills must be inserted into the classroom practices. Students must be more than just understanding the core subjects, and they have to have strong foundations of knowledge and skills to face the century of globalization and technology era.

To respond to the demands, the teachers as the agents of changes in the classroom must be ready with this change and be knowledgeable about the world's development. Knowledge brings changes to human life aspects, including economic, social, and technological changes [4]. Thus, being knowledgeable in 21st-century education is an obligation for any teacher, and they have to be ready to face the challenges. The teachers are essential factors who play a vital role in preparing students for mastering 21st-century skills [5].

The literature results show plenty of research studies investigating the teachers' readiness to promote 21 st-century skills. Some studies found that the teachers are ready and aware of the importance of technology in 21 st-century learning, but they have less confidence in using the technology in daily teaching [6-8]. Besides, there is a significant correlation between the academic level and understanding 21st-century learning skills [7].

There has been a lot of research conducted related to the teachers' readiness to implement 21 st-century skills. The previous research revealed that 21 st-century skills are essentials. Teachers' perception and preparation are linked to one another in implementing 21 st-century skills, which bring good outcomes $[7,9,10]$. 
Although a lot of research was conducted on teacher readiness in implementing 21 st-century skills, limited research was conducted on primary school teachers' readiness to promote 21st-century skills in teaching English as a foreign language in a bilingual context. The scarcity of research on this topic inspires this research to be conducted. For that reason, the study's purpose was to analyze the teachers' readiness to promote 21 st-century skills and investigate how the skills are implemented in classroom practices.

\section{REVIEW OF LITERATURE}

Readiness in the context of language teaching deals with being prepared to teach students. Preparation can be in terms of knowledge, attitude, and preparation to implement the instruction in the classroom. In facing $21^{\text {st }}$-century education, readiness can be interpreted as being prepared to face the changes as demanded by the new era of the $21^{\text {st }}$ century. Thus, readiness directly links to the changes [11]. For that reason, along with the development of $21^{\text {st }}$-century education, teachers should be prepared with all the changes to prepare students to survive in this century.

Readiness is a condition in which the school staffs are well prepared to engage in particular agenda to make some improvements [12]. Readiness is related to one's tendency or willingness to do an action [13]. Therefore, readiness is both a condition and process associated with a change to improve [11]. Referring to those definitions, it can be inferred that teachers' readiness is dealing with the preparation of the teachers to deal with changes needed for improving the quality of their teaching-learning process.

The readiness of the teachers is essentially needed to be capable of promoting $21^{\text {st }}$-century skills into classroom practices. Education in the 21st-century is prepared for the challenges faced in globalization and internationalization [1]. Having enough knowledge about $21^{\text {st }}$-century education and skills is vital to surviving in life. The teachers must lead the students to face the changes happening nowadays in this globalization century.

There are several $21^{\text {st }}$-century skills needed to be promoted in classroom practices. Those skills are life and career skills, learning and innovation skills, media, literacy, and technology skills. The life and career skills consist of flexibility and adaptability, initiative and self-direction, social and crosscultural interaction, productivity and accountability, leadership, and responsibility. Learning and Innovation skills consist of collaboration and communication, creativity and innovation, critical thinking and problem-solving skills, and the last skills deal with Information literacy, Media literacy, and Information and Communication Technology literacy. In addition to those three skills, there are nine core subjects in 21 st-century themes, such as English, reading or language arts, World languages, Arts, Mathematics, Economics, Science, Geography, History, Government, and Civics. In addition to the core subjects, there are five $21^{\text {st }}$ century interdisciplinary themes. First is global awareness, which means using $21^{\text {st }}$-century skills to understand global issues. Second is financial, economic, business, and entrepreneurial literacy to face $21^{\text {st }}$-century economics demand. Third is civic literacy, which means to understand local and global civic implications. Fourth is health literacy, which means that understand necessary health information to enrich self-health. The last is environmental literacy, which means demonstrating knowledge and understanding of the environment towards caring for the environment. All of those are important to be mastered by both teachers and students $[14,15]$.

Concerning $21^{\text {st }}$-century education, six types of expertise must be mastered by teachers to be considered as ready for the $21^{\text {st }}$ century. They are mastering knowledge/content, mastering $21^{\text {st }}$-century pedagogy, mastering the skills in tracing students development, mastering learning phycology skills, possess counseling skills, and competent in using technology and media [7]. These skills are the foundation for teaching students in this century.

\section{METHODS}

This study was in the form of a mixed-method design, which dominantly applied the qualitative method and supported by quantitative analysis. This design was conducted into two stages. The first one was the stage to gain quantitative data, which used a questionnaire, and the second phase was a stage to gain qualitative data through observation and interview. The results of the data were presented descriptively.

This research took place in a bilingual school in Buleleng regency. There were 11 teachers involved who all have English Education background, and the range of working experiences is from 2 up to 8 years of teaching. As a bilingual school, the medium of instruction is in two languages, such as Bahasa Indonesia as the students' national language and English. Bahasa Indonesia is used especially to reemphasize the key concepts introduced in English. The main instruments were the researchers and supported with a questionnaire. The data about teachers' perceived readiness were collected using a questionnaire that has been evaluated by expert judges in terms of its reliability and validity before its usage. To guarantee the data's trustworthiness, direct observations were conducted and followed by interviewing the teachers to triangulate the questionnaire's data. The data were analyzed using simple descriptive statistics to calculate the teachers' perceived readiness and supported with qualitative analysis that analyzes the observations and interviews results.

\section{RESULT AND DISCUSSION}

Referring to the study's purposes, the findings are classified into two parts. The first one is about the readiness as perceived by the teachers themselves. The second one is the teachers' readiness as observed to investigate and analyze the actual implementations. The perceived readiness was collected by asking the teachers to self-assess their understanding of the $21^{\text {st }}$-century skills, which was conducted by answering a questionnaire. Table 1 is the summary of the data regarding the teachers' readiness as how they perceived themselves. Each of the skills was elaborated into several indicators (17 indicators 
altogether), and the teachers were demanded to self-assess their readiness.

TABLE I. THE TEACHERS' PERCEIVED READINESS IN PROMOTING THE 21ST-CENTURY SKILLS

\begin{tabular}{|c|c|c|c|c|c|}
\hline No & Dimensions & \multicolumn{4}{|c|}{ Teachers' Perceived Readiness On 21 } \\
Century Skills
\end{tabular}

The teachers have a good understanding of 21 st-century skills, including the following skills, and are ready to insert them into the process of teaching and learning.

\begin{tabular}{|c|c|c|c|}
\hline 1. & $\begin{array}{l}\text { Life and Career } \\
\text { skills }\end{array}$ & $18 \%$ & $82 \%$ \\
\hline 2 & $\begin{array}{l}\text { Learning and } \\
\text { Innovation } \\
\text { skills }\end{array}$ & $9 \%$ & $91 \%$ \\
\hline 3 & $\begin{array}{l}\text { Media, literacy, } \\
\text { technology } \\
\text { skills }\end{array}$ & $27 \%$ & $73 \%$ \\
\hline 4 & $\begin{array}{l}\text { Themes of the } \\
21^{\text {st }} \text {-century } \\
\text { framework. }\end{array}$ & $100 \%$ & \\
\hline & Average & & \\
\hline
\end{tabular}

Table I indicates that all teachers perceived themselves as having a good understanding of the 21 st-century skills and are ready to insert them into the process of teaching and learning in the classroom. All teachers chose the options of "agree" and "strongly agree" in the questionnaire, which indicates that they are all confident with their understanding and feeling ready to insert them into the classroom practices. The questionnaire results are logical because it was informed during the interviews with the school principal and the teachers that the school management always controls the teachers' readiness in teaching their students, and their readiness is always updated through weekly workshops. The teachers have to attend a professional development workshop every Friday, and during the workshops, they are introduced to new information to update the teachers' knowledge. Besides, the teachers are also given chances to share their problems with their team or the school principal and discuss the appropriate problem-solving strategies. With this effort and weekly programs conducted at the school, it is not surprising that all teachers feel very ready to promote $21^{\text {st }}$-century skills in their classroom practices. These results are in line with the previous studies that confirmed teachers are ready to promote $21^{\text {st }}$-century skills in their classes [7,8].

Direct observations were conducted to know whether the teachers are truly ready to implement the skills in the actual implementations. The results of the observation can be explained in the following sections.

The English teachers' readiness to implement the 21stcentury skills needs to be investigated to analyze how far the teachers are ready in promoting the skills in the classroom practices. Table 2 shows the summary information of the teachers' readiness in implementing the 21 st-century skills.
TABLE II. THE TEACHERS' READINESS IN PROMOTING THE 21STCENTURY SKILLS

\begin{tabular}{|c|c|c|}
\hline Aspects & $\begin{array}{c}\text { The Results Of } \\
\text { Observation }\end{array}$ & Remark \\
\hline Lesson Plan & $\begin{array}{l}\text { The teachers were } \\
\text { ready to implement } \\
21^{\text {st }- \text { century }} \\
\text { education because } \\
\text { they promote the } \\
\text { skills in their lesson } \\
\text { plans. }\end{array}$ & $\begin{array}{l}\text { The skills were promoted in the } \\
\text { teaching-learning process's } \\
\text { objectives in the lesson plans and } \\
\text { implemented in the co-curricular } \\
\text { programs (Literacy Program, } \\
\text { Novel Study, House Program, } \\
\text { Community Service Program, and } \\
\text { Entrepreneurship Program. }\end{array}$ \\
\hline $\begin{array}{l}\text { Teaching } \\
\text { and } \\
\text { Learning } \\
\text { Process }\end{array}$ & $\begin{array}{l}\text { In the teaching and } \\
\text { learning process, } \\
\text { teachers at the } \\
\text { school showed they } \\
\text { were very ready to } \\
\text { teach the students } \\
\text { based on } 21^{\text {st }} \\
\text { century education. }\end{array}$ & $\begin{array}{l}\text { The teaching process uses the } \\
\text { philosophy of constructivism, } \\
\text { differentiated instruction, and the } \\
\text { whole-person approach, so the } \\
\text { method of teaching is student- } \\
\text { centered. Many real-rife literacies } \\
\text { are introduced and trained in the } \\
\text { classroom, where all the } 21^{\text {st }} \text { - } \\
\text { century skills are naturally trained } \\
\text { and developed. }\end{array}$ \\
\hline Assessment & $\begin{array}{l}\text { On the assessment } \\
\text { part of the teaching } \\
\text { and learning } \\
\text { process, it was } \\
\text { found that the } \\
\text { teachers were very } \\
\text { ready to insert } 21^{\text {st }} \text { - } \\
\text { century education in } \\
\text { their assessment. }\end{array}$ & $\begin{array}{l}\text { The assessments used are } \\
\text { authentic based assessments, } \\
\text { which are real-life and project- } \\
\text { based where the students are } \\
\text { demanded to use their knowledge } \\
\text { in real-life experiences, so the } \\
21^{\text {st }} \text {-century skills are part of the } \\
\text { competencies that are blended in } \\
\text { the classroom practices. The } \\
\text { competencies are natural and } \\
\text { authentic because some of the } \\
\text { assessments were conducted in } \\
\text { spontaneous performances. }\end{array}$ \\
\hline
\end{tabular}

From Table II, it is clear that the teachers manifested their readiness in every aspect of teaching. The $21^{\text {st }}$-century skills become the spirit of all activities conducted, which are promoted in the lesson plans of classroom practices and during the teaching-learning activities, in the assessments, and implemented in the co-curricular activities conducted at the school level involving all students at the school. A lesson plan is a guidance made and used by the teachers in the teaching and learning process, which consists of teaching objectives, activities, and the assessment of the learning process [16]. Teachers have to be literate about using media and technology to access, manage, and select the information for the teaching and learning process [17]. This is also reconfirmed during the interviews that all teachers are ready and capable of using a digital learning management system for blended learning.

As evidence of the implementations, some pictures are presented in this paper. 


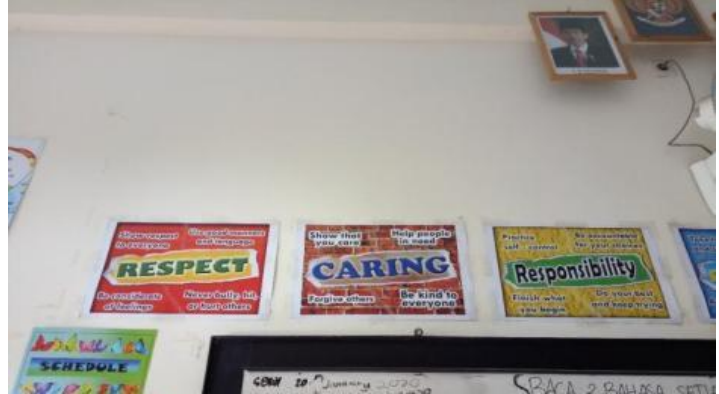

Fig. 1. The theme of character values.

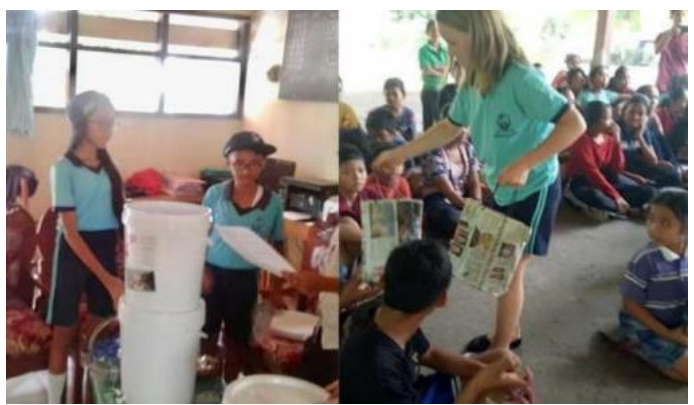

Fig. 2. Students' activities of sharing and caring.

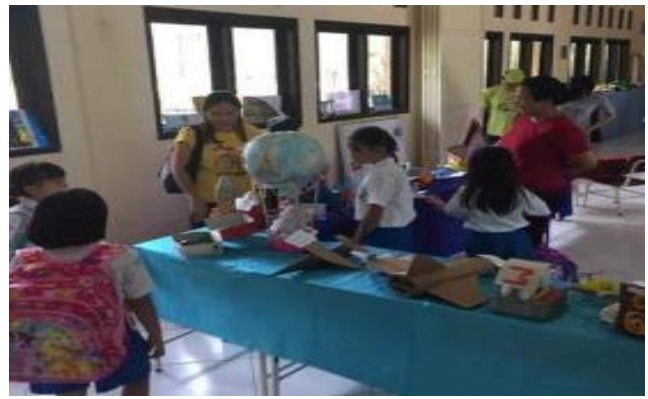

Fig. 3. Students' Gallery.

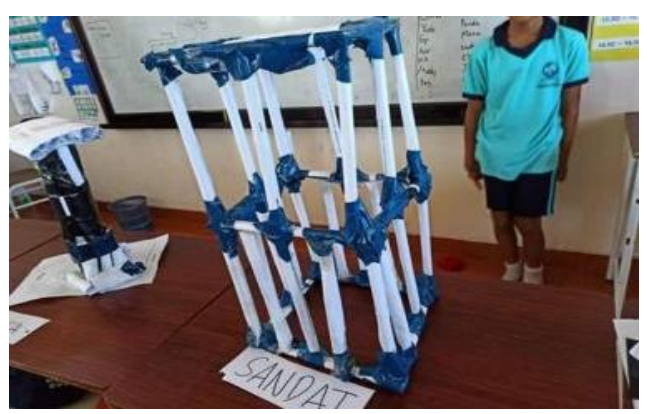

Fig. 4. Making paper tower.

Based on the results of observation, it can be interpreted that the teachers performed their readiness, which was reflected in the tasks and activities conducted by the students. Picture 1. shows how the life skills themes are used as the themes of references of any activities in the school. The themes were manifested into programs, each used as the activities' focus rotated every month. The interview results reveal that co- curricular programs are directed to the themes of character values and manifested in project-based activities monthly.

The second part of Picture 2 is one example of social and cross-cultural activities conducted when the students were explaining the system of water filter donated for students in the village school. In this event, the students must be able to communicate and explain a water filter system. It was observed that the students show their competencies to communicate effectively and how to share kindness with other students. Besides, they did it in manners that are socially and culturally appropriate. The second part of Picture 2 also shows social care to other students.

Picture 3 is about the gallery. This is one sample of the activities which stimulate creativity. Students are directed to produce something using materials available or recycled ones. Each student's product is displayed, and students can invite parents and relatives to visit their gallery. In this event, the students were asked to explain the product in Bahasa Indonesia and English if parents do not speak the students' language.

Picture 4 shows the result of a group project. In this project, the students were trained to use their critical thinking and problem-solving strategy to design a paper tower. The students have to discuss with their group members how to make a tower using light material like paper so that it can stand by itself. Many discussions were needed, and the students were allowed to find information and asked questions to their teacher. After they finished doing the tower, they have to explain the product to all students during the assembly day.

Besides the activities shown in the pictures, there are a lot of programs conducted manifesting 21st-century skills. The programs were basically in the form of projects/task-based from which the students' skills of scientific activities were trained and developed. There are five learning steps in a scientific approach that should be implemented in classroom practices, such as observing, questioning, experimenting, associating, and communicating, all in line with the school's activities [18].

The activities conducted by the students at the school indicate that the students have been trained on how to collaborate and self-direct themselves. This is very important in this century because 21 st-century students must be equipped with self-direction and the ability to collaborate with individuals, groups, and machines [19]

Assessing the students' performances is needed to judge the teaching and learning process's quality and monitor the students' progress and understanding. Assessment is an evaluation done by the teacher by checking students' work, behavior, and achievement [20]. Teachers' readiness to promote 21 st-century skills in their assessment is also shown from the various assessment types conducted at the school. The teachers used authentic assessments that promote 21 st-century skills that demand students to perform their authentic competencies in natural settings. 
The fact that the school uses a bilingual system is an advantageous condition that encourages students to use English as a medium of instruction in the classroom and using Bahasa Indonesia. The exposure of English usage as daily communication chains to and with the English teachers and students of native English speaking provides more beneficial opportunities for the students in their communication skills. Their skills of reading English novels and presenting ideas in English are also indicators of communication competencies of the students. Besides, the students' critical thinking also improves well, which is indicated in the students' quality of book reviews. This is also reconfirmed in the students' tabloid and the quality of the story summaries assigned to them.

The teachers' activities and programs for the students reflect that the teachers are truly ready to promote 21 st-century skills in their classroom. Their readiness impacts the quality of the teaching-learning process. These results are related to the previous study about the teachers' and students' perception, which found that teachers who are well prepared in implementing the skills impacted the output of the learning process [10]. The results showed that the students enjoyed the activities in the learning process. The teachers felt the significant differences and benefits in implementing the 21 stcentury skills. The output showed that the students' have good critical thinking and collaborative skills during the lesson. It linked to the teachers' perception that their students already have and implemented the skills well.

Analyzing the way the teachers treated students and made interactions with their students at the school, it can be stated that the teachers manifested their competencies in their daily performance of teaching appropriately. There are four teachers' competencies: personality, social, professional, and pedagogical competencies, which influence their teaching roles [21]. Thus, teachers play essential roles in the students' development [7]. In line with teachers' competencies, teachers must deal with their cognitive, interpersonal, and intrapersonal skills [22]. Through the competency, teachers know their abilities to teach the students. All the competencies determine the teachers' readiness, and the teachers' readiness determines the teachers' quality of teaching. The teaching-learning process's quality determines the students' achievements [7], [23].

21 st-century education brings changes and improvements in students through classroom activities [24,25]. The activities promoting $21^{\text {st }}$-century skills must be introduced since primary education. Primary education is a foundation before other educations [26]. It means the quality of teaching and learning in primary school is vital as an education foundation. Therefore, the teachers' role and the teachers' readiness in implementing 21st-century education framework in primary schools are essential. A teacher's role is helping students achieve the goals in learning and the mission of education [27].

Although this research was conducted in a bilingual school, the study's findings can inspire other teachers who also teach English and are needed to promote 21 st-century skills in classroom practices. Further research involving more teachers and regular schools is recommended to see whether similar results are found.

\section{CONCLUSION}

The teachers' readiness to promote 21 st-century skills is manifested in their teaching quality and indicated in their students' successful learning. Implementing various activities and programs that are project-based and utilized performancebased learning activities shows how the teachers implement the skills in the teaching-learning process. The results of authentic assessments reveal the students' competencies, not only about the mastery of the subject content. It is also about the competencies of 21 st-century skills reflected in school programs' implementations and direct communications with society. It is implied that the teachers' perceived readiness and the actual implementation are not different, and both represent high readiness.

\section{REFERENCES}

[1] H. Boholano, "Smart social networking: 21st century teaching and learning skills," Res. Pedagog., vol. 7, no. 1, pp. 21-29, 2017, doi: 10.17810/2015.45.

[2] B. Triling and C. Fadel, 21st century skills. Learning for life in our times, First. New York: John Wiley \& Sons, 2009

[3] D. A. Saputri, "Analysis of teachers' readiness in teaching English to young learners at kindergartens (A study of the kindergartens in Salatiga in the academic year of," State Institute of Islamic Studies Salatiga, 2016.

[4] H. Jan, "Teacher of 21st century: characteristic and development," Reserach Humanit. Scoial Sci., vol. 7, no. 9, pp. 50-54, 2017, doi: https://www.researchgate.net/publication/318468323\%0ATeacher.

[5] T. K. R. Singh and S. Chan, "Teacher readiness on ICT integration in teaching-learning: a Malaysian case study," Int. J. Asian Soc. Sci., vol. 4, no. 7, pp. 874-885, 2014.

[6] N. H. Julaihi and A. Hamdan, "Malaysian Secondary School Teachers' Readiness in Implementing 21st Century Learning (PAK21," DEStech Trans. Soc. Sci., vol. 7, no. 9, pp. 50-54, 2019, [Online]. Available: https://www.researchgate.net/publication/318468323\%0ATeacher.

[7] N. M. Rusdin, "Teachers' Readiness in Implementing 21st Century Learning," Int. J. Acad. Res. Bus. Soc. Sci., vol. 8, no. 4, pp. 1293 1306, 2018, doi: 10.6007/IJARBSS/v8-i4/4270.

[8] N. Ibrahim, A. Adzra'ai, R. Sueb, and S. F. Dalim, "Trainee teachers' readiness towards 21 st century teaching practices," Asian J. Univ. Educ., vol. 15, no. 1, pp. 1-12, 2019.

[9] V. Tuzlukova, S. Al Busaidi, S. Burns, and G. Bugon, "Exploring teachers' perceptions of $21 \mathrm{St}$ century skills in teaching and learning in English language classrooms in Oman's higher education institutions," J. Teach. English Specif. Acad. Purp., vol. 6, no. 1, p. 191, 2018, doi: 10.22190/jtesap1801191t.

[10] S. Warner and A. Kaur, "The perceptions of teachers and students on a 21st century mathematics instructional model," Int. Electron. J. Math. Educ., vol. 12, no. 2, pp. 193-215, 2017.

[11] C. C. Dalton and L. N. Gottlieb, "The concept of readiness to change," J Adv. Nurs., vol. 42, no. 2, pp. 108-117, 2003, doi: 10.1046/j.13652648.2003.02593.x

[12] D. E. Lynch and R. Smith, "Readiness for school reform," Int. J. Innov. Creat. Chang., vol. 2, no. 3, 2016.

[13] R. A. Nasution, L. S. L. Rusnandi, E. Qodariah, D. Arnita, and N. A. Windasari, "The Evaluation of Digital Readiness Concept: Existing Models and Future Directions," Asian J. Technol. Manag., vol. 11, no. 2, pp. 94-117, 2018, doi: 10.12695/ajtm.2018.11.2.3 
[14] Partnership for 21st Century Skills, 21st Century Student Outcomes. 2009.

[15] H. A. S. Syamsuri and Ishaq, Guru, generasi Z, dan alah : pembelajaran abad 21. Repositori Unismuh.Ac.Id, 2010.

[16] I. Khan, "Lesson planning for teaching English Lesson planning for reading: an effective teaching strategy in EFL classrooms," Elixir Soc. Stud., vol. 37, no. September, pp. 3958-3964, 2011.

[17] T. K. R. Singh and S. Chan, "Teacher readiness on ICT integration in teaching-learning: a Malaysian case study,” Int. J. Asian Soc. Sci., vol. 4, no. 7, pp. 874-885, 2014.

[18] J. H. Dyer, H. B. Gregersen, and C. M. Christensen, Five Discovery Skills that Distinguish Great Innovators. Harvard: Harvard Business School, 2011.

[19] I. J. McCoog, 21st Century teaching and learning. Utah: Education Resource Center, 2008.

[20] E. T. Amua-Sekyi, "Assessment, Student Learning, and Classroom Practice: A Review," J. Educ. Pract., vol. 7, no. 21, pp. 1-6, 2016, [Online].

Available: http://search.ebscohost.com/login.aspx?direct=true $\& d b=$ eric $\& A N=E J 11$ 09385\&site=ehost-live.

[21] M. Z. I. Sumual and M. Ali, "Evaluation of primary school teachers" pedagogical competence in implementing curriculum," J. Educ. Learn., vol. 11 , no. 3, pp. 343-350, 2017.
[22] S. B. Shum and R. D. Crick, "Learning analytics for 21st century competencies," J. Learn. Anal., vol. 3, no. 2, pp. 6-21, 2016, doi: https://doi.org/S0167-4781(97)00063-8.

[23] K. Lim and E. Tay, "Preparing Teachers for the 21st century," AsTEN J. Teach. Educ., vol. 1, no. 1, 2016.

[24] N. N. Padmadewi, L. Artini, and P. K. Nitiasih, "Techniques for building character and literacy for 21 st century education," Adv. Soc. Sci. Educ. Humanit. Res., vol. 173, pp. 250-253, 2018, doi: 10.2991/icei-17.2018.65.

[25] E. Y. Wijaya, D. A. Sudjimat, and A. Nyoto, "Transformasi pendidikan abad 21 sebagai tuntutan pengembangan sumber daya manusia di era global," in Prosiding Seminar Nasional Pendidikan Matematika, 2016, vol. 1, pp. 263-278, doi: http://repository.unikama.ac.id/840/32/263278.

[26] C. R. Etor, U. F. Mbon, and E. E. Ekanem, "Primary education as a foundation for qualitative higher education in Nigeria," J. Educ. Learn. vol. 2, no. 2, pp. 155-164, 2013, doi: 10.5539/jel.v2n2p155.

[27] M. N. Ulum, "Penyusunan lesson plan berbasis multiple intelligences research studi atas karya munif chatib," J. Ilm. Pedagog., vol. 7, no. 1, pp. 37-59, 2017. 